\title{
The NEW ENGLAND JOURNAL of MEDICINE
}

ESTABLISHED IN 1812

NOVEMBER 20, 2003

VOL. 349 NO. 21

\section{Combination Antiretroviral Therapy and the Risk of Myocardial Infarction}

\author{
The Data Collection on Adverse Events of Anti-HIV Drugs (DAD) Study Group*
}

\section{ABSTRACT}

BACKGROUN D

It remains controversial whether exposure to combination antiretroviral treatment increases the risk of myocardial infarction.

\section{METHODS}

In this prospective observational study, we enrolled 23,468 patients from 11 previously established cohorts from December 1999 to April 2001 and collected follow-up data until February 2002. Data were collected on infection with the human immunodeficiency virus and on risk factors for and the incidence of myocardial infarction. Relative rates were calculated with Poisson regression models. Combination antiretroviral therapy was defined as any combination regimen of antiretroviral drugs that included a protease inhibitor or a nonnucleoside reverse transcriptase inhibitor.

\section{RESULTS}

Over a period of 36,199 person-years, 126 patients had a myocardial infarction. The incidence of myocardial infarction increased with longer exposure to combination antiretroviral therapy (adjusted relative rate per year of exposure, 1.26 [95 percent confidence interval, 1.12 to 1.41]; $\mathrm{P}<0.001$ ). Other factors significantly associated with myocardial infarction were older age, current or former smoking, previous cardiovascular disease, and male sex, but not a family history of coronary heart disease. A higher total serum cholesterol level, a higher triglyceride level, and the presence of diabetes were also associated with an increased incidence of myocardial infarction.

\section{CONCLUSIONS}

Combination antiretroviral therapy was independently associated with a 26 percent relative increase in the rate of myocardial infarction per year of exposure during the first four to six years of use. However, the absolute risk of myocardial infarction was low and must be balanced against the marked benefits from antiretroviral treatment.
Address reprint requests to Dr. Jens D. Lundgren, DAD Coordinating Center, Copenhagen HIV Program, Section 044, Hvidovre University Hospital, 2650 Copenhagen, Denmark, or at jdl@cphiv.dk (Dr. Lundgren).

*The members of the DAD study group are listed in the Appendix.

N EnglJ Med 2003;349:1993-2003.

Copyright $\odot 2003$ Massachusetts Medical Society. 
LTHOUGH THE BENEFITS OF COMBInation antiretroviral therapy have revolutionized the care of patients with human immunodeficiency virus type 1 (HIV-1) infection, increasingly severe treatment-associated metabolic side effects have been observed, among them dyslipidemia, insulin resistance, and overt diabetes mellitus, which are well-known risk factors for cardiovascular disease. ${ }^{1-6}$ These side effects may increase the risk of premature myocardial infarction, although direct evidence of such an association is inconsistently reported in the existing literature. ${ }^{7-19}$

To address this concern, and as part of an initiative by the European Agency for the Evaluation of Medicinal Products, the Data Collection on Adverse Events of Anti-HIV Drugs (DAD) Study was initiated in 1999. The primary objective of the study was to determine whether exposure to combination antiretroviral therapy is independently associated with the risk of myocardial infarction.

\section{METHODS}

\section{DESIGN}

The study methods have been described previously. ${ }^{5}$ In brief, we conducted a collaborative, observational study of 11 previously established cohorts comprising 23,468 HIV-1-infected patients followed at 188 clinics in 21 countries in Europe, the United States, and Australia.

The primary study end point was myocardial infarction. The study was designed to permit the detection of a twofold difference in the incidence of myocardial infarction between two equal groups according to their exposure to combination antiretroviral therapy. A total of at least 100 new cases of myocardial infarction were required to give the study sufficient power to detect such an increase in risk (two-sided type I error, 5 percent; power, 90 percent). On the basis of preliminary data from the EuroSIDA study, the incidence of myocardial infarction in these HIV-1-infected persons was assumed to be 3.3 per 1000 person-years (Kirk O: personal communication), and hence the study had to collect at least 30,000 person-years of follow-up data before the primary objective could be examined.

\section{COLLECTION OF DATA}

Patients were followed prospectively during their regular visits to outpatient clinics. Eligible patients were all under active follow-up in their individual cohorts at the time of enrollment in the study, irrespective of their antiretroviral-treatment status. Pa- tients were consecutively enrolled in the study from clinics in each of the participating cohorts beginning in December 1999; enrollment was complete by April 2001. At enrollment and at least every eight months thereafter, standardized data-collection forms were completed at the sites to provide information about the patients' family history of coronary heart disease, their history of cardiovascular disease or diabetes, cigarette smoking, blood pressure, therapy for diabetes mellitus, lipid-lowering and antihypertensive therapy, clinical signs of lipodystrophy, and serum lipid levels (levels of total cholesterol, high-density lipoprotein [HDL] cholesterol, and triglycerides). Dyslipidemia was defined according to the U.S. National Cholesterol Education Program cutoff values for high-risk levels. ${ }^{20}$

The presence of lipodystrophy was defined subjectively and not verified objectively. ${ }^{21}$ Because information distinguishing peripheral fat loss and central fat accumulation was not collected from all the cohorts, it was not possible to perform an analysis that distinguished these phenotypes. Information on the patients' characteristics since inclusion in any of the cohorts, including information on demographic characteristics, antiretroviral therapy, surrogate markers of HIV-1 infection, and clinical course, was also collected. ${ }^{22}$ All the information collected was transformed into a standardized format and merged into a central data set. We present the data merged in July 2002 (the third merger).

\section{ASCERTAIN MENT OF OUTCOMES}

All new cases of myocardial infarction were reported to the study coordinating office for central validation and for coding according to procedures applied in the World Health Organization Multinational Monitoring of Trends and Determinants in Cardiovascular Disease (MONICA) Project. ${ }^{23-25}$ All events had to satisfy the criteria for a definite, possible, or unclassifiable myocardial infarction and were categorized as nonfatal (when the patient survived to 28 days after onset) or fatal. The diagnosis was based on an established algorithm ${ }^{25}$ adapted from standardized criteria that included cardiac pain, cardiac enzyme or troponin levels, electrocardiographic readings, and in cases of death, autopsy results if available. Nonfatal myocardial infarctions not associated with clinical symptoms were not included.

\section{QUALITY ASSURANCE AND GOVERNANCE}

The training of study and medical personnel for each cohort and at each site was performed before the initiation of the study. Site monitoring was con- 
ducted annually and included a review of source documents for all the reported end points and all cases of death and an audit of the case notes for a random sample of 10 percent of the remaining patients.

The study was supervised by a steering committee with scientific and organizational independence from the financial sponsor of the study, a consortium of pharmaceutical companies that market licensed antiretroviral agents in Europe and the United States. Until the study reached the predetermined number of person-years of follow-up, members of the steering committee remained blinded to the number of end points that had occurred. An external expert from the MONICA project evaluated the documentation of primary end points, and before the event data base and main study data base were merged, an end-point committee reviewed the classification of the primary events.

\section{STATISTICAL ANALYSIS}

All analyses were based on calculations of the incidence rate, with base line being the time of enrollment. Only follow-up and events that occurred prospectively, after enrollment, were counted in the analyses. Follow-up ceased on the earliest of the following: the date of a primary end-point event, the date of death (if applicable), February 1, 2002, and the date six months after the patient's last contact for HIV-1-related care (defined as the most recent CD4+ cell count or HIV-1 RNA measurement, initiation of a new antiretroviral regimen, or diagnosis of a new acquired immunodeficiency syndrome [AIDS]-defining illness).

To describe the relation between the incidence of myocardial infarction and exposure to combination antiretroviral therapy, each person's follow-up was divided into a series of consecutive one-month periods. A patient's cumulative exposure to therapy at the start of each period was calculated (including the duration of treatment before enrollment in this study and during follow-up), and the result was used to assign the patient-month (and any endpoint events that occurred during that month) to the appropriate exposure category. The exposure categories were as follows: no exposure or less than one year, one to two years, two to three years, three to four years, and more than four years of exposure. Follow-up data from patients with more than five years of exposure were limited. The incidence rate in each of these categories was calculated as the number of events occurring divided by the total number of patient-years in that category.

If a person discontinued therapy, his or her ex- posure category remained what it had been at the time of discontinuation; cumulative exposure subsequently increased only if a patient restarted therapy. No distinction was made among treatment regimens, including regimens based on protease inhibitors or nonnucleoside reverse transcriptase inhibitors.

Poisson regression models (GENMOD Procedure, SAS software, version 6.12) were used to quantify the relation between exposure to therapy and the risk of myocardial infarction, after adjustment for possible differences in the cardiovascular risk profile of patients in each exposure category. Visual assessment of the incidence rates in each category confirmed that a linear relation between exposure and incidence was a reasonable assumption. Thus, exposure was incorporated as a continuous variable in these analyses.

The primary model was adjusted for demographic factors (age, body-mass index [the weight in kilograms divided by the square of the height in meters], race, presence or absence of a family history of coronary heart disease, smoking status, and sex), mode of HIV-1 transmission, cohort, and presence or absence of preexisting cardiovascular disease before enrollment. Age was considered a timeupdated, continuous variable and was recalculated at the start of each patient-month. All the other variables were treated as fixed categorical variables and took the same value for a given patient at the start of each month. Data were complete for exposure to combination antiretroviral treatment and age; however, for all the other variables, specific categories were generated for missing data to ensure that all patients were included in the analyses.

In additional exploratory analyses we assessed the influence of base-line markers of HIV-1 infection (CD4+ cell count and HIV-1 RNA level at the time of enrollment; nadir CD4+ cell count and peak HIV-1 RNA level before enrollment; and known duration of HIV-1 infection [defined according to the dates of the earliest CD4+ cell count, HIV-1 RNA level, AIDS-defining event, or treatment episode]), the presence or absence of a prior AIDS-defining event, and the presence or absence of lipodystrophy. Also analyzed was the influence of established risk factors for myocardial infarction that may potentially be influenced by combination antiretroviral therapy, including the levels of plasma lipids (total cholesterol, HDL cholesterol, and triglycerides [ $\log _{2}$-transformed]), the presence of hypertension (defined by a systolic blood pressure of $150 \mathrm{~mm} \mathrm{Hg}$ or above, a diastolic blood pressure of $100 \mathrm{~mm}$ Hg or above, or 
the use of antihypertensive agents), and the presence of diabetes mellitus. Variables that change over time (e.g., lipid levels and hypertension-related variables) were fitted separately both as fixed covariates (baseline values only) and as time-updated variables.

\section{SENSITIVITY ANALYSIS}

In the primary analyses, five myocardial infarctions that occurred after the censoring date were exclud- ed. Analyses were repeated with follow-up data censored on February 1, 2002, or on the date of a myocardial infarction or death. In additional sensitivity analyses, we considered the incidence of all end points (including eight recurrent myocardial infarctions, which occurred more than 28 days after a first primary end-point event); excluded data from patients with a prior cardiovascular event; excluded unclassifiable or possible events; and adjusted for

\begin{tabular}{|c|c|c|c|}
\hline Characteristic & Value & Characteristic & Value \\
\hline Female sex - no. (\%) & $5,652(24.1)$ & Exposure to combination antiretroviral & \\
\hline Age $-\mathrm{yr}$ & & therapy $\mathbb{9}$ & \\
\hline Median & 39 & Patients exposed - no. (\%) & $17,484(74.5)$ \\
\hline Interquartile range & $34-45$ & Cumulative exposure $-\mathrm{yr}$ & \\
\hline Mode of HIV-1 transmission - no. (\%) & & Median & $\begin{array}{c}1.9 \\
0-32\end{array}$ \\
\hline Homosexual transmission & $10,563(45.0)$ & Interquartile range & \\
\hline $\begin{array}{l}\text { Heterosexual transmission } \\
\text { Intravenous drug use }\end{array}$ & $\begin{array}{l}6,142(26.2) \\
4,578(19.5)\end{array}$ & $\begin{array}{l}\text { Exposure to nucleoside reverse-transcriptase } \\
\text { inhibitors } \mathbb{}\end{array}$ & \\
\hline Other or unknown & $2,185(9.3)$ & Patients exposed - no. (\%) & $18,915(80.6)$ \\
\hline Known duration of HIV-1 infection $-\mathrm{yr}$ & & No. of drugs per patient & \\
\hline $\begin{array}{l}\text { Median } \\
\text { Range }\end{array}$ & $\begin{array}{c}3.5 \\
0-20.3\end{array}$ & $\begin{array}{l}\text { Median } \\
\text { Range }\end{array}$ & $\begin{array}{c}2 \\
0-7\end{array}$ \\
\hline Previous AIDS — no. (\%) & $6,152(26.2)$ & $\begin{array}{l}\text { Cumulative exposure }-\mathrm{yr} \\
\text { Median }\end{array}$ & 2.7 \\
\hline CD4+ cell count - per mm $m^{3} \dagger$ & & Interquartile range & $0.6-4.4$ \\
\hline $\begin{array}{l}\text { Nadir before base line } \\
\text { Median }\end{array}$ & 226 & $\begin{array}{l}\text { Exposure to nonnucleoside reverse-transcriptase } \\
\text { inhibitors } \mathbb{}\end{array}$ & \\
\hline $\begin{array}{l}\text { Interquartile range } \\
\text { At base line }\end{array}$ & $94-398$ & Patients exposed - no. (\%) & $7,979(34.0)$ \\
\hline At base line & & No. of drugs per patient & \\
\hline Median & 418 & Median & 0 \\
\hline Interquartile range & $255-612$ & Range & $0-3$ \\
\hline HIV-I RNA level - $\log _{10}$ copies $/ \mathrm{mlt}$ & & Cumulative exposure $-\mathrm{yr}$ & \\
\hline Maximum before base line & & Median & 0 \\
\hline Median & 4.6 & Interquartile range & $0-0.5$ \\
\hline Range & $3.6-5.2$ & Exposure to protease inhibitors $\mathbb{R}$ & \\
\hline At base line & & Patients exposed - no. (\%) & $15,747(67.1)$ \\
\hline Median & $<2.7$ & No. of drugs per patient & \\
\hline Range & $<2.7-6.9$ & Median & 1 \\
\hline No previous antiretroviral therapy - no. (\%) & $4,506(19.2)$ & Range & $0-6$ \\
\hline Exposure to antiretroviral drugs $\mathbb{\pi}$ & & Cumulative exposure $-\mathrm{yr}$ & \\
\hline Patients exposed - no. (\%) & $18,962(80.8)$ & Median & 1.6 \\
\hline No. of drugs per patient & & Interquartile range & $0-3.0$ \\
\hline Median & 4 & & \\
\hline Range & $0-15$ & & \\
\hline Cumulative exposure $-\mathrm{yr}$ & & & \\
\hline Median & 2.8 & & \\
\hline Interquartile range & $0.6-4.5$ & & \\
\hline
\end{tabular}

* Information on race was unavailable for 10,419 patients (44.4 percent of the cohort); among those with available information, 9862 (75.6 percent) were white, 2391 (18.3 percent) were black, and 796 (6.1 percent) belonged to other races. HIV-1 denotes human immunodeficiency virus type 1 , and AIDS acquired immunodeficiency syndrome.

$\dagger$ Data were available for 22,526 patients. The median time from measurement of the nadir CD4+ lymphocyte count to base line was 1.6 years (range, 0 to 15.0 ).

$\Varangle$ Data were available for 22,567 patients. The median time from measurement of the maximal HIV RNA count to base line was 1.2 years (range, 0 to 15.0 .

$\int$ Information on the number of drugs per patient and on cumulative exposure is provided for the entire cohort, not only for those exposed.

9 Combination antiretroviral therapy was defined as any antiretroviral drug regimen containing three or more drugs, one of which was a protease inhibitor or a nonnucleoside reverse-transcriptase inhibitor. 
calendar time. None of these sensitivity analyses affected the conclusions drawn from the main analyses (data not shown).

\section{RESULTS}

\section{BASE-LINE CHARACTERISTICS}

The study cohort included 23,468 HIV-1-infected patients; 24.1 percent were women, and the median age of the patients was 39 years. The median known duration of HIV-1 infection was 3.5 years, and 26.2 percent of the patients had previously been found to have AIDS (Table 1). At base line, 80.8 percent of the study population had been exposed to at least one antiretroviral drug and 74.5 percent to combi- nation antiretroviral therapy. Overall, the median cumulative exposure to combination antiretroviral therapy was 1.9 years. Because of differences in the dates when various drug classes were first marketed, the rate of exposure to protease inhibitors was substantially higher and the duration substantially longer than the rate and duration of exposure to nonnucleoside reverse transcriptase inhibitors.

In this relatively young population, the prevalence of previous cardiovascular disease was only 1.5 percent (Table 2). However, many of the subjects had cardiovascular risk factors: 56.2 percent were current or previous smokers and 2.8 percent had diabetes, 7.2 percent hypertension, and 45.9 percent dyslipidemia.

\begin{tabular}{|c|c|c|c|}
\hline Variable & Value & Variable & Value \\
\hline Body-mass index- & & Total cholesterolt' & 21.1 \\
\hline$>30$ (\% of patients) & 4.8 & $\geq 6.2 \mathrm{mmol} /$ liter (\% of patients) & 5.0 \\
\hline Median & 23.0 & Median (mmol/liter) & $4.2-6.0$ \\
\hline Interquartile range & $21.0-25.2$ & Interquartile range ( $\mathrm{mmol} /$ liter) & \\
\hline Current or former smoker (\% of patients) $\ddagger$ & 56.2 & HDL cholesterol $\dagger^{\dagger} \uparrow$ & \\
\hline Family history of coronary heart disease & & $\leq 0.9 \mathrm{mmol} / \mathrm{liter}$ (\% of patients) & 26.1 \\
\hline$(\%$ of patients $) \mathbb{\int}$ & 11.7 & Median (mmol/liter) & 1.1 \\
\hline Previous cardiovascular disease (\% of patients) & 1.5 & Interquartile range ( $\mathrm{mmol} /$ liter) & $0.9-1.4$ \\
\hline Hypertension (\% of patients) $\|$ & 7.2 & $\begin{array}{l}\text { Ratio of total to HDL cholesterol't' } \\
\geq 6.5 \text { (\% of patients) }\end{array}$ & 18.6 \\
\hline Systolic pressure $(\mathrm{mm} \mathrm{Hg})$ & & Median & $\begin{array}{r}10.0 \\
4.5\end{array}$ \\
\hline Median & 120 & Interquartile range & $3.5-6.0$ \\
\hline $\begin{array}{c}\text { Interquartile range } \\
\text { Diastolic pressure }(\mathrm{mm} \mathrm{Hg})\end{array}$ & $110-130$ & Triglycerides $+\hat{t}$ & \\
\hline Median & 80 & $\geq 2.3 \mathrm{mmol} /$ liter (\% of patients) & 32.2 \\
\hline Interquartile range & $70-80$ & Median (mmol/liter) & 1.7 \\
\hline Diabetes mellitus (\% of patients) & 2.8 & Interquartile range (mmol/liter) & $1.1-2.7$ \\
\hline & & Dyslipidemia (\% of patients) $\int \mathbb{\int}$ & 45.9 \\
\hline & & Lipodystrophy (\% of patients) $१ \uparrow$ & 21.9 \\
\hline & & Use of lipid-lowering agents (\% of patients) \|\| & 3.7 \\
\hline
\end{tabular}

* One participating cohort (comprising 10.6 percent of the total number of patients in the study) did not collect data on smoking status, the presence or absence of a family history of cardiovascular disease, the presence or absence of hypertension, or the use or nonuse of lipid-lowering agents. Patients with missing information were excluded from the denominator of this calculation.

$\dagger$ The body-mass index is the weight in kilograms divided by the square of the height in meters. Information was missing for 4311 of the patients (18.4 percent).

$t$ Information was missing for 4939 of the patients (21.0 percent).

$\int$ Patients were considered to have a family history of coronary heart disease at base line if they had a first-degree relative who had had a myocardial infarction before the age of 50 years. Information was missing for 8680 of the patients ( 37.0 percent).

If A previous cardiovascular event was defined as a myocardial infarction, stroke, or invasive cardiovascular procedure before base line.

I. Hypertension at base line was defined as a systolic blood pressure of $150 \mathrm{~mm} \mathrm{Hg}$ or higher, a diastolic blood pressure of $100 \mathrm{~mm} \mathrm{Hg}$ or higher, or the use of antihypertensive drugs. Information was missing for 4848 patients (20.7 percent).

$*$ Diabetes mellitus at base line was defined as a laboratory diagnosis of this condition or the use of antidiabetic drugs.

†TInformation on the total cholesterol level was missing for 6275 of the patients (26.7 percent); information on the high-density lipoprotein (HDL) cholesterol level was missing for 15,002 of the patients (63.9 percent); and information on the ratio of total to HDL cholesterol was missing for 15,120 of the patients (64.4 percent). To convert the values for cholesterol to milligrams per deciliter, divide by 0.02586 .

Information was missing for 6371 of the patients (27.1 percent). To convert the values for triglycerides to milligrams per deciliter, divide by 0.01129 .

$\iint$ Dyslipidemia at base line was defined as the presence of an abnormal value for any of the four lipid factors (total cholesterol, HDL cholesterol, ratio of total to HDL cholesterol, and triglycerides).

919Information was missing for 3098 of the patients (13.2 percent).

\|\| Information was missing for 2974 of the patients (12.7 percent). 


\section{FOLLOW-UP}

The median time between clinic visits (according to assessments of $\mathrm{CD} 4+$ cells) during the prospective follow-up period was three months, without consistent differences according to the duration of exposure to combination antiretroviral therapy. The total number of person-years of prospective followup until the first new myocardial infarction or until the censoring date for those who remained free of myocardial infarction was 36,199 (median individual follow-up time, 1.6 years [interquartile range, 1.3 to 1.9]). A total of 1909 participants (8.1 percent) had no reported clinic visits during the 12 months before February 1, 2002. During the follow-up period, 566 patients ( 2.4 percent) were known to have died; 36 of the deaths ( 6.4 percent) were due to myocardial infarction, and 26 (4.6 percent) were due to other cardiovascular events, such as stroke.

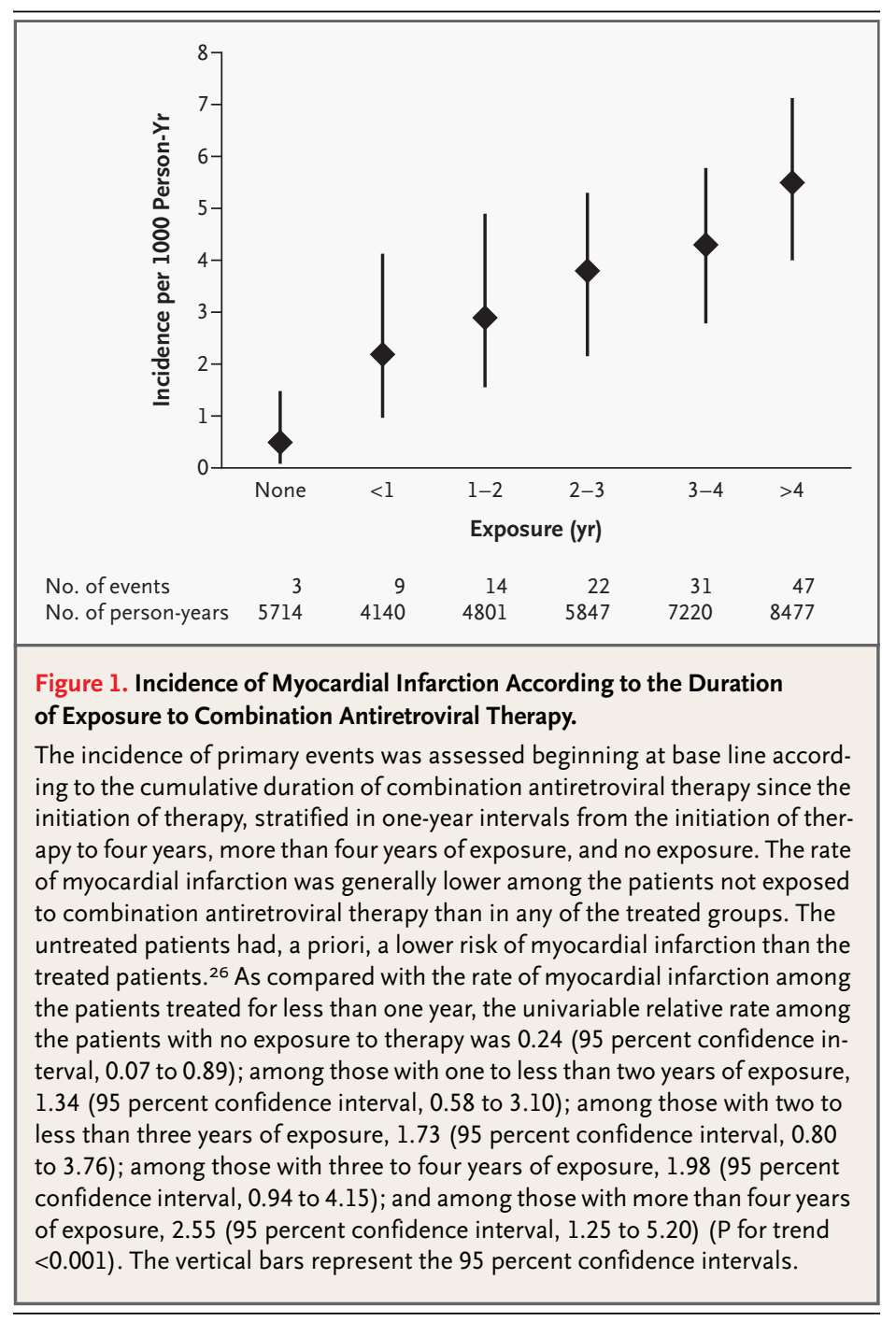

\section{INCIDENCE OF MYOCARDIAL INFARCTION}

A total of 126 patients had a myocardial infarction during follow-up (incidence, 3.5 events per 1000 person-years). Fifty-five percent of the myocardial infarctions were categorized as definite and 29 percent as possible; 16 percent were considered unclassifiable. One hundred fourteen of the infarctions ( 90 percent) occurred in men. Thirty-six of the events ( 29 percent) were fatal; 16 of the deaths were considered to have been caused by an unclassifiable coronary event (such as sudden death).

The incidence of myocardial infarction increased with increasing exposure to combination antiretroviral therapy (P for trend, <0.001) (Fig. 1). The patients with no exposure to therapy had a lower incidence of myocardial infarction than for any of the treated groups. Because the incidence increased gradually with more extended exposure, exposure time was fitted as a continuous variable in subsequent models. Fitted this way, the relative rate was 1.22 (95 percent confidence interval, 1.09 to 1.38 ) per additional year of exposure to combination antiretroviral therapy; it was 1.26 ( 95 percent confidence interval, 1.12 to 1.41 ) after adjustment for demographic risk factors, including age, which increased with increasing duration of therapy (Table 3 ).

Other factors that also independently predicted myocardial infarction were increased age, current or past smoking, previous cardiovascular disease, and male sex, but not a family history of coronary heart disease (Table 3). The primary model also included the cohort, race, body-mass index, and mode of HIV-1 transmission, but in adjusted analyses none of these variables were independently associated with the occurrence of myocardial infarction. Intentionally, the model did not include variables such as plasma lipid concentrations, which could potentially be on the causal pathway from drug exposure to myocardial infarction.

\section{METABOLIC DISORDERS AND MARKERS OF HIV DISEASE}

Individual models were developed for each of the variables listed in Table 4, which also included all the variables in the primary model. At base line and during the prospective follow-up period, the following numbers of metabolic measurements were available for analysis: 82,619 for total cholesterol, 82,341 for triglycerides, and 50,241 for blood pressure. Hypertension was present or developed in 2574 patients, diabetes in 717, and lipodystrophy in 6716.

At base line and during follow-up, increased total cholesterol levels, increased triglyceride levels, 
and the presence of diabetes were all associated with an increased risk of myocardial infarction (Table 4). The presence of hypertension at base line was not significantly associated with the risk of myocardial infarction, whereas the analysis of time-updated values did reveal an increased risk. The presence of lipodystrophy at any time was not significantly associated with the risk of myocardial infarction.

The association between combination antiretroviral therapy and the risk of myocardial infarction tended to decrease in the models that included total cholesterol or triglyceride levels, but not in those

\begin{tabular}{|c|c|c|c|c|}
\hline \multirow[t]{2}{*}{ Variable } & \multicolumn{2}{|c|}{ Univariable Model } & \multicolumn{2}{|c|}{ Multivariable Model } \\
\hline & $\begin{array}{l}\text { Relative Rate } \\
\quad(95 \% \mathrm{Cl})\end{array}$ & P Value & $\begin{array}{l}\text { Relative Rate } \\
\quad(95 \% \mathrm{Cl})\end{array}$ & P Value \\
\hline $\begin{array}{l}\text { Exposure to combination antiretroviral therapy } \\
\text { (per additional yr) }\end{array}$ & $1.22(1.09-1.38)$ & $<0.001$ & $1.26(1.12-1.41)$ & $<0.001$ \\
\hline Age (per additional $5 \mathrm{yr}$ ) & $1.44(1.34-1.55)$ & $<0.001$ & $1.38(1.26-1.50)$ & $<0.001$ \\
\hline Male sex & $3.07(1.69-5.57)$ & $<0.001$ & $1.99(1.04-3.79)$ & 0.04 \\
\hline Body-mass indext & & 0.78 & & 0.77 \\
\hline$<18$ & $0.60(0.15-2.44)$ & & $0.54(0.13-2.23)$ & \\
\hline $18-26 \pi$ & 1.00 & & 1.00 & \\
\hline $26-30$ & $1.20(0.72-2.01)$ & & $1.00(0.60-1.69)$ & \\
\hline$>30$ & $1.21(0.53-2.78)$ & & $1.28(0.55-2.98)$ & \\
\hline Unknown & $0.88(0.54-1.44)$ & & $0.80(0.45-1.41)$ & \\
\hline Mode of HIV-l transmission & & 0.32 & & 0.28 \\
\hline Homosexual』 & 1.00 & & 1.00 & \\
\hline Heterosexual & $0.69(0.44-1.08)$ & & $1.13(0.69-1.88)$ & \\
\hline Intravenous drug use & $0.76(0.47-1.23)$ & & $1.49(0.88-2.55)$ & \\
\hline Other & $0.32(0.04-2.31)$ & & $0.30(0.04-2.19)$ & \\
\hline Unknown & $0.98(0.50-1.90)$ & & $1.40(0.68-2.86)$ & \\
\hline Race & & 0.002 & & 0.60 \\
\hline White』 & 1.00 & & 1.00 & \\
\hline Black & $0.52(0.26-1.03)$ & & $0.82(0.36-1.90)$ & \\
\hline Other & $0.19(0.03-1.34)$ & & $0.32(0.04-2.38)$ & \\
\hline Unknown & $0.55(0.38-0.81)$ & & $0.91(0.46-1.81)$ & \\
\hline Family history of coronary heart disease & & 0.44 & & 0.78 \\
\hline Nod & 1.00 & & 1.00 & \\
\hline Yes & $1.50(0.83-2.72)$ & & $1.18(0.64-2.17)$ & \\
\hline Unknown & $1.07(0.74-1.55)$ & & $1.18(0.66-2.13)$ & \\
\hline Smoking status & & 0.007 & & 0.007 \\
\hline Current or former & $2.08(1.28-3.39)$ & & $2.17(1.30-3.62)$ & \\
\hline Never』 & 1.00 & & 1.00 & \\
\hline Unknown & $1.73(0.95-3.18)$ & & $1.39(0.57-3.38)$ & \\
\hline Previous cardiovascular disease & & $<0.001$ & & $<0.001$ \\
\hline Nol & 1.00 & & 1.00 & \\
\hline Yes & $13.77(8.62-21.99)$ & & $5.84(3.51-9.72)$ & \\
\hline
\end{tabular}

* All 23,468 patients were included in the models shown. Estimates of the relative rate were obtained from univariable and multivariable Poisson regression models. $\mathrm{Cl}$ denotes confidence interval.

$\dagger$ In addition to the variables shown, the multivariable model was adjusted for cohort. No significant differences in the rates of myocardial infarction were observed between cohorts.

$T$ The body-mass index is the weight in kilograms divided by the square of the height in meters.

$\int$ The patients in this category served as the reference group. 


\begin{tabular}{|c|c|c|c|c|}
\hline \multirow[t]{2}{*}{ Variable } & \multicolumn{2}{|c|}{ Effect of the Variable } & \multicolumn{2}{|c|}{$\begin{array}{l}\text { Effect of Exposure to Combination } \\
\text { Antiretroviral Therapy } \\
\text { (per Additional Year) }\end{array}$} \\
\hline & $\begin{array}{l}\text { Relative Rate } \\
\quad(95 \% \mathrm{Cl})\end{array}$ & P Value & $\begin{array}{l}\text { Relative Rate } \\
\quad(95 \% \mathrm{CI})\end{array}$ & P Value \\
\hline None & - & - & $1.26(1.12-1.41)$ & $<0.001$ \\
\hline $\begin{array}{l}\text { Total cholesterol (per increase of } 1 \mathrm{mmol} / \text { liter) } \\
\text { At base line } \\
\text { Time-updated }\end{array}$ & $\begin{array}{l}1.16(1.04-1.30) \\
1.18(1.08-1.28)\end{array}$ & $\begin{array}{c}0.01 \\
<0.001\end{array}$ & $\begin{array}{l}1.16(1.00-1.35) \\
1.20(1.05-1.36)\end{array}$ & $\begin{array}{l}0.05 \\
0.007\end{array}$ \\
\hline $\begin{array}{l}\text { Triglycerides (per doubling) } \\
\text { At base line } \\
\text { Time-updated }\end{array}$ & $\begin{array}{l}1.39(1.12-1.73) \\
1.48(1.23-1.79)\end{array}$ & $\begin{array}{r}0.003 \\
<0.001\end{array}$ & $\begin{array}{l}1.14(0.98-1.32) \\
1.16(1.02-1.33)\end{array}$ & $\begin{array}{l}0.09 \\
0.03\end{array}$ \\
\hline $\begin{array}{l}\text { Hypertension } \\
\text { At base line } \\
\text { Time-updated }\end{array}$ & $\begin{array}{l}1.67(0.99-2.81) \\
1.90(1.20-3.02)\end{array}$ & $\begin{array}{c}0.06 \\
<0.001\end{array}$ & $\begin{array}{l}1.26(1.12-1.42) \\
1.25(1.11-1.41)\end{array}$ & $\begin{array}{l}<0.001 \\
<0.001\end{array}$ \\
\hline $\begin{array}{l}\text { Diabetes } \\
\text { At base line } \\
\text { Time-updated }\end{array}$ & $\begin{array}{l}2.38(1.38-4.10) \\
2.32(1.35-3.99)\end{array}$ & $\begin{array}{l}0.002 \\
0.002\end{array}$ & $\begin{array}{l}1.25(1.11-1.41) \\
1.25(1.11-1.41)\end{array}$ & $\begin{array}{l}<0.001 \\
<0.001\end{array}$ \\
\hline $\begin{array}{l}\text { Lipodystrophy } \\
\text { At base line } \\
\text { Time-updated }\end{array}$ & $\begin{array}{l}0.70(0.45-1.09) \\
0.69(0.45-1.07)\end{array}$ & $\begin{array}{l}0.11 \\
0.10\end{array}$ & $\begin{array}{l}1.28(1.14-1.44) \\
1.28(1.14-1.44)\end{array}$ & $\begin{array}{l}<0.001 \\
<0.001\end{array}$ \\
\hline $\begin{array}{l}\text { Known duration of HIV-1 infection at base line } \\
\text { (per additional yr) }\end{array}$ & $1.01(0.93-1.09)$ & 0.85 & $1.27(1.11-1.44)$ & $<0.001$ \\
\hline AIDS before enrollment & $0.93(0.62-1.37)$ & 0.70 & $1.26(1.12-1.42)$ & $<0.001$ \\
\hline $\begin{array}{l}\mathrm{CD} 4+\text { cell count (per increase of } 50 \text { cells } / \mathrm{mm}^{3} \text { ) } \\
\text { Minimum before base line } \\
\text { At base line }\end{array}$ & $\begin{array}{l}1.01(0.96-1.06) \\
1.00(0.97-1.04)\end{array}$ & $\begin{array}{l}0.84 \\
0.88\end{array}$ & $\begin{array}{l}1.27(1.12-1.44) \\
1.27(1.13-1.43)\end{array}$ & $\begin{array}{l}<0.001 \\
<0.001\end{array}$ \\
\hline $\begin{array}{l}\text { HIV-1 RNA level (per increase of } \log _{10} \text { copies } / \mathrm{ml} \\
\text { Maximum before base line } \\
\text { At base line }\end{array}$ & $\begin{array}{l}1.11(0.92-1.34) \\
0.94(0.75-1.18)\end{array}$ & $\begin{array}{l}0.27 \\
0.60\end{array}$ & $\begin{array}{l}1.27(1.12-1.43) \\
1.27(1.12-1.43)\end{array}$ & $\begin{array}{l}<0.001 \\
<0.001\end{array}$ \\
\hline $\begin{array}{l}\text { The variables included are metabolic and physiol } \\
\text { retroviral therapy and thus may be on the causal } \\
\text { Poisson regression models. In each row, the relat } \\
\text { roviral therapy are also adjusted for the variables } \\
\text { HIV-1 human immunodeficiency virus type } 1 \text {, an } \\
\text { Univariable results were in the same direction as } \\
\text { (e.g., univariable relative rate at base line, } 1.25 \text { [ } 9 \\
\text { To convert the value to milligrams per deciliter, } d\end{array}$ & $\begin{array}{l}\text { gical variables that } \\
\text { thway. Estimates o } \\
\text { e rates for the give } \\
\text { hown in Table } 3 \text { (or } \\
\text { AIDS acquired imn } \\
\text { e adjusted results } \\
\text { percent confidence } \\
\text { ide by } 0.02586 \text {. }\end{array}$ & $\begin{array}{l}\text { an be ind } \\
\text { the relativ } \\
\text { variable a } \\
\text { model pe } \\
\text { unodeficie } \\
\text { r all the va } \\
\text { interval, } 0\end{array}$ & $\begin{array}{l}\text { or influenced by com } \\
\text { te were obtained from } \\
\text { for exposure to combin } \\
\text { w). Cl denotes confide } \\
\text { syndrome. } \\
\text { oles tested, except for l } \\
\text { to } 1.89]) \text {. }\end{array}$ & $\begin{array}{l}\text { ination anti- } \\
\text { iultivariable } \\
\text { tion antiret- } \\
\text { ice interval, } \\
\text { odystrophy }\end{array}$ \\
\hline
\end{tabular}

that included diabetes, hypertension, or lipodystrophy (Table 4). In addition, when total cholesterol and triglyceride levels were included in the same model, the association with therapy was not further affected (relative rate, 1.16 [95 percent confidence interval, 1.02 to 1.33$]$ ).

None of the markers of HIV-1 disease were associated with myocardial infarction in the adjusted model. Including these variables in the model did not modify the association between duration of exposure to combination antiretroviral therapy and myocardial infarction.

\section{I SCUSSION}

Although the absolute event rate was low, combination antiretroviral therapy was associated with a 26 percent relative increase in the rate of myocardial infarction per year of exposure during the first four to six years of use. This finding is plausible because combination antiretroviral therapy can cause adverse metabolic changes that are known risk factors for cardiovascular disease. However, only randomized trials might be able to prove whether the observed association reflects a causal relation. In 
addition, the relative increase in the risk of myocardial infarction per year cannot be extrapolated beyond the duration of follow-up in the study.

Previous studies have reached conflicting conclusions on this issue, some supporting our findings ${ }^{12,17,18}$ and others not. ${ }^{13-16}$ Most studies have been retrospective in nature and, to varying degrees, have had other limitations, including short exposure times, a small number of end points, the use of composite end points, changes in hospital admission policies over time, and lack of source verification for the end points. Two of the largest three studies failed to detect a relation, ${ }^{15,16}$ whereas the third did. ${ }^{18}$ Both of the studies that did not detect a relation were based on retrospective extraction of hospital admission codes from administrative data bases. One ${ }^{15}$ reported a surprising decrease in admission rates over time, which may be explained by changes in admission policies as well as selection and ascertainment biases. The other ${ }^{16}$ reported comparable admission rates among patients who were receiving protease inhibitors and those who were not. However, a recent update ${ }^{19}$ suggested that the rate of admission increased over time and with longer periods of exposure to protease inhibitors, although the analysis was based on few events and was not tested statistically for significance.

Our method has several advantages over those applied in prior studies. First and most important, it was a prospective study, and thus it was possible to implement extensive quality-assurance measures at the outset to ensure that all myocardial infarctions were documented according to predefined standards. ${ }^{23-25}$ Second, myocardial infarction was intentionally chosen as the primary end point, since the ascertainment of other cardiovascular events was considered to be less precise. Third, a diverse study population was achieved by enrolling patients from a variety of geographic areas, including substantial numbers of women and members of minority groups. Thus, our cohort reflects the diverse makeup of the HIV-1-infected population in industrialized countries.

Our method does have some limitations, however. We were unable to identify an appropriate cohort of HIV-1-negative persons with a similar background risk of myocardial infarction. Hence, our key objective was to assess changes in risk according to the duration of exposure to combination antiretroviral therapy. Since the median prospective follow-up time in this study was less than two years, a comparison based on the duration of exposure to combination antiretroviral therapy is essentially a comparison of patients who start therapy in different calendar years. Although adjustment for calendar time did not influence the findings, patients who started therapy in different years may have had different profiles of risk for myocardial infarction, and if so, we may not have been able to adjust for all those differences. However, we found no evidence to suggest that the duration of HIV-1 infection, the level of prior immunodeficiency, or the degree of HIV-1 RNA replication affected the association between exposure to therapy and the risk of myocardial infarction. Moreover, none of these variables had any independent effect on the risk of myocardial infarction. Finally, because of insufficient power, we are unable at the present time to examine the risk associated with individual drugs or drug classes. As the study continues, our ability to address these issues will improve.

In an attempt to elucidate a possible mechanism of the relation between combination antiretroviral therapy and myocardial infarction, we carried out preliminary analyses to examine whether the association was modified by adjusting for metabolic and physiological variables previously noted to have been influenced by antiretroviral therapy. The results suggest that the total cholesterol and triglyceride levels have a possible role. Conversely, significant contributions from diabetes, hypertension, and lipodystrophy were not identified. Further follow-up, with additional data on myocardial infarctions, will be necessary before firmer conclusions can be drawn.

Combination antiretroviral therapy substantially improves the prognosis of HIV-1-infected patients at risk for AIDS. Before the availability of such therapy, the annual mortality rate among patients with HIV-1 infection exceeded 20 percent, ${ }^{27}$ as compared with less than 2 percent in the current study. Furthermore, among the patients who died, only 6.4 percent died from myocardial infarction; progression of HIV-1-related disease was the leading cause of death. Finally, the annual rate of myocardial infarction, even among those exposed to therapy for four to six years, was less than 0.6 percent, and only a portion of the apparent excess risk could be attributed to combination antiretroviral therapy. Other known risk factors for myocardial infarction probably contributed to the occurrence of these events. ${ }^{26}$ Hence, the substantial benefits of combination antiretroviral therapy continue clearly to outweigh the increased risk of myocardial infarction associated with this therapy. However, atherosclerosis may take decades to progress to a clinically detectable de- 
gree, ${ }^{28}$ and thus further follow-up of our cohort is necessary to determine whether a substantial absolute increase in morbidity and mortality from therapy-related cardiovascular disease will emerge. ${ }^{29,30}$

Supported by the Oversight Committee for the Evaluation of Metabolic Complications of HAART, a collaborative committee with representation from academic institutions, the European Agency for the Evaluation of Medicinal Products, the Food and Drug Administration, the patient community, and all pharmaceutical companies with licensed anti-HIV drugs in the U.S. market: Abbott, Agouron, Boehringer Ingelheim, Bristol-Myers Squibb, GlaxoSmithKline, Merck, Pfizer, and Hoffmann-LaRoche.

Supported by a grant (CURE/97-46486) from the Health Insurance Fund Council, Amstelveen, the Netherlands, to the AIDS Therapy Evaluation Project Netherlands (ATHENA); by a grant from the Agence Nationale de Recherches sur le SIDA (Action Coordonnée no. 7 , Cohortes), to the Aquitaine Cohort; by the Commonwealth
Department of Health and Ageing and a grant from the Australian National Council on AIDS, Hepatitis C and Related Diseases' Clinical Trials and Research Committee, to the Australian HIV Observational Database (AHOD); by grants from the Fondo de Investigación Sanitaria (FIS 99/0887) and Funación para la Investigación y la Prevención del SIDA en España (FIPSE 3171/00), to the Barcelona Antiretroviral Surveillance Study (BASS); by the National Institute of Allergy and Infectious Diseases, National Institutes of Health (grants 5U01AI042170-10 and 5U01AI046362-03), to the Terry Beirn Community Programs for Clinical Research on AIDS (CPCRA); by grants from the BIOMED 1 (CT94-1637) and BIOMED 2 (CT97-2713) programs and the fifth framework program (QLK22000-00773) of the European Commission and grants from BristolMyers Squibb, GlaxoSmithKline, Boehringer Ingelheim, and Roche, to the EuroSIDA study; by an unrestricted educational grant from Glaxo Wellcome, Italy, to the Italian Cohort Naive to Antiretrovirals (ICONA); and by a grant (3345-062041) from the Swiss National Science Foundation, to the Swiss HIV Cohort Study (SHCS).

APPENDIX

The members of the DAD study group are as follows: Writing committee: Nina Friis-Mфller (Copenhagen), Caroline A. Sabin (London), Rainer Weber (Zurich), Antonella d'Arminio Monforte (Milan), Wafaa M. El-Sadr (New York), Peter Reiss (Amsterdam), Rodolphe Thiébaut (Bordeaux), Linda Morfeldt (Stockholm), Stephane De Wit (Brussels), Christian Pradier (Nice), Gonzalo Calvo (Barcelona), Matthew G. Law (Sydney), Ole Kirk (Copenhagen), Andrew N. Phillips (London), and Jens D. Lundgren (Copenhagen); steering committee: J.D. Lundgren (chair), R. Weber (SHCS), A. d'Arminio Monforte (ICONA), G. Bartsch (CPCRA), P. Reiss (ATHENA), F. Dabis (Aquitaine), L. Morfeldt (HivBivus), S. De Wit (Brussels St. Pierre Cohort), C. Pradier (Nice Cohort), G. Calvo (BASS), M.G. Law (AHOD), O. Kirk (EuroSIDA), A.N. Phillips, F. Houyez, E. Loeliger, R. Tressler, and I. Weller; central coordination: N. Friis-Mфller, C.A. Sabin, A. Sjфl (verification of primary end point), and J.D. Lundgren; data management: A. Sawitz (coordinator), M. Rickenbach, P. Pezzotti, E. Krum, R. Meester, V. Lavignolle, A. Sundström, B. Poll, E. Fontas, F. Torres, K. Petoumenos, and J. Kjær; independent advisory panel: S. Hammer, J. Neaton, and A. Sjфl.

The members of the 11 cohorts are as follows: ATHENA: Central coordination: F. de Wolf, E. van der Ven, S. Zaheri, I. Van Valkengoed, and R. Meester; participating physicians: W. Bronsveld, H. Weigel, K. Brinkman, P. Frissen, J. ten Veen, M. Hillebrand, P. van Dam, S. Schieveld, J. Mulder, E. van Gorp, P. Meenhorst, A. van Eeden, S. Danner, F. Claessen, R. Perenboom, J.K. Eeftinck Schattenkerk, M. Godfried, J. Lange, S. Lowe, J. van der Meer, F. Nellen, K. Pogany, T. van der Poll, J. Prins, P. Reiss, T. Ruys, M. van der Valk, F. Wit, C. Richter, R. van Leusen, R. Vriesendorp, F. Jeurissen, R. Kauffmann, E. Koger, B. Bravenboer, C. ten Napel, H.G. Sprenger, G. Law, R.W. ten Kate, M. Leemhuis, F. Kroon, E. Schippers, G. Schrey, S. van der Geest, A. Verbon, P. Koopmans, M. Keuter, D. Telgt, A. van der Ven, M. van der Ende, I. Gyssens, S. de Marie, J. Juttmann, C. van der Heul, M. Schneider, J. Borleffs, I. Hoepelman, C. Jaspers, A. Matute, C. Schurink, and W. Blok. Aquitaine (France): Scientific committee: R. Salamon (chair), J. Beylot, M. Dupon, M. Le Bras, J.L. Pellegrin, and J.M. Ragnaud; central coordination: F. Dabis, G. Chêne, H. Jacqmin-Gadda, R. Rhiébaut, S. Lawson-Ayayi, V. Lavignolle, E. Balestre, M.J. Blaizeau, M. Decoin, A.M. Formaggio, S. Delveaux, S. Labarerre, B. Uwamaliya, E. Vimard, L. Merchadou, G. Palmer, D. Touchard, D. Dutoit, F. Pereira, and B. Boulant; participating physicians: J. Beylot, P. Morlat, N. Bernard, M. Bonarek, F. Bonnet, B. Coadou, P. Gelie, D. Jaubert, C. Nouts, D. Lacoste, M. Dupon, H. Dutronc, G. Cipriano, S. Lafarie, I. Chossat, J.Y. Lacut, B. Leng, J.L. Pellegrin, P. Mercié, J.F. Viallard, I. Faure, P. Rispal, C. Cipriano, S. Tchamgoué, M. Le Bras, F. Djossou, D. Malvy, J.P. Pivetaud, J.M. Ragnaud, D. Chambon, C. De La Taille, T. Galperine, S. Lafarie, D. Neau, A. Ochoa, C. Beylot, M.S. Doutre, J.H. Bezian, J.F. Moreau, J.L. Taupin, C. Conri, J. Constans, P. Couzigou, L. Castera, H. Fleury, M.E. Lafon, B. Masquelier, I. Pellegrin, P. Trimoulet, F. Moreau, C. Mestre, C. Series, A. Taytard. AHOD (Australia): Central coordination: M. Law, K. Petoumenos; participating physicians: J. Anderson, J. Bal, A. Mijch, K. Watson, N. Roth, H. Wood, D. Austin, A. Gowers, D. Baker, R. McFarlane, A. Carr, D. Cooper, J. Chuah, W. Fankhauser, S. Mallal, and J. Skett. BASS (Spain): Central coordination: G. Calvo, F. Torres, and S. Mateau; participating physicians: P. Domingo, M.A. Sambeat, J. Gatell, E. Del Cacho, J. Cadafalch, M. Fuster, C. Codina, G. Sirera, and A. Vaqué. The Brussels St. Pierre Cohort (Belgium): N. Clumeck, S. De Wit, M. Gerard, M. Hildebrand, K. Kabeya, D. Konopnicki, M.C. Payen, B. Poll, and Y. Van Laethem. CPCRA (United States): Central coordination: J. Neaton, G. Bartsch, W.M. El-Sadr, E. Krum, G. Thompson, and D. Wentworth; participating physicians: R. Luskin-Hawk, E. Telzak, W.M. El-Sadr, D.I. Abrams, D. Cohn, N. Markowitz, R. Arduino, D. Mushatt, G. Friedland, G. Perez, E. Tedaldi, E. Fisher, F. Gordin, L.R. Crane, J. Sampson, and J. Baxter. EuroSIDA (multinational): Central coordination: O. Kirk, A. Mocroft, A.N. Phillips, and J.D. Lundgren; participating physicians: Austria - N. Vetter; Belgium - N. Clumeck, P. Hermans, and R. Colebunders; Czech Republic — L. Machala; Denmark - J. Nielsen, T. Benfield, J. Gerstoft, T. Katzenstein, B. Røge, P. Skinh $\phi$ j, and C. Pedersen; France - C. Katlama, J.-P. Viard, T. Saint-Marc, P. Vanhems, and C. Pradier; Germany - M. Dietrich, C. Manegold, J. van Lunzen, V. Miller, S. Staszewski, M. Bieckel, F.D. Goebel, B. Salzberger, and J. Rockstroh; Greece — J. Kosmidis, P. Gargalianos, H. Sambatakou, J. Perdios, G. Panos, I. Karydis, and A. Filandras; Hungary — D. Banhegyi; Ireland — F. Mulcahy; Israel — I. Yust, D. Turner, S. Pollack, Z. Ben-Ishai, Z. Bentwich, and S. Maayan; Italy - S. Vella, A. Chiesi, C. Arici, R. Pristerá, F. Mazzotta, A. Gabbuti, R. Esposito, A. Bedini, A. Chirianni, E. Montesarchio, V. Vullo, P. Santopadre, P. Narciso, A. Antinori, P. Franci, M. Zaccarelli, A. Lazzarin, R. Finazzi, and A. D'Arminio Monforte; Luxembourg - R. Hemmer and T. Staub; the Netherlands — P. Reiss; Norway - J. Bruun, A. Maeland, and V. Ormaasen; Poland - B. Knysz, J. Gasiorowski, A. Horban, D. Prokopowicz, A. Boron-Kaczmarska, M. Pynka, M. Beniowski, and H. Trocha; Portugal - F. Antunes, K. Mansinho, and R. Proenca; Spain - J. González-Lahoz, B. Diaz, T. García-Benayas, L. Martin-Carbonero, V. Soriano, B. Clotet, A. Jou, J. Conejero, C. Tural, J.M. Gatell, and J.M. Miró; Sweden - A. Blaxhult, B. Heidemann, and P. Pehrson; Switzerland - B. Ledergerber, R. Weber, P. Francioli, A. Telenti, B. Hirschel, V. Soravia-Dunand, and H. Furrer; United Kingdom - M. Fisher, R. Brettle, S. Barton, A.M. Johnson, D. Mercey, C. Loveday, M.A. Johnson, A. Pinching, J. Parkin, J. Weber, and G. Scullard. HivBivus (Sweden): Central coordination: L. Morfeldt, G. Thulin, and A. Sundström; participating physicians: B. Åkerlund, K. Koppel, A. Karlsson, L. Flamholc, and C. Håkangård. ICONA (Italy): Central coordination: A. d’Arminio Monforte, P. Pezzotti; participating physicians: M. Moroni, A. d'Arminio Monforte, A. Cargnel, S. Merli, G.M. Vigevani, C. Pastecchia, A. Lazzarin, R. Novati, L. Caggese, C. Moioli, M.S. Mura, M. Mannazzu, F. Suter, C. Arici, P.E. Manconi, P. Piano, F. Mazzotta, S. Lo Caputo, A. Poggio, G. Bottari, G. Pagano, A. Alessandrini, A. Scasso, A. 
Vincenti, V. Abbadesse, S. Mancuso, F. Alberici, A. Ruggieri, M. Arlotti, P. Ortolani, F. De Lalla, G. Tositti, N. Piersantelli, R. Piscopo, E. Raise, S. Pasquinucci, F. Soscia, L. Tacconi, U. Tirelli, G. Nasti, D. Santoro, L. Pusterla, G. Carosi, F. Castelli, G. Cadeo, D. Vangi, G. Carnevale, D. Galloni, G. Filice, R. Bruno, A. Sinicco, M. Sciandra, P. Caramello, L. Gennero, M.L. Soranzo, M. Bonasso, G. Rizzardini, G. Migliorino, F. Chiodo, V. Colangeli, G. Magnani, M. Ursitti, F. Menichetti, C. Martinelli, R. Esposito, C. Mussini, F. Ghinelli, L. Sighinolfi, O. Coronado, T. Zauli, G. Ballardini, M. Montroni, A. Zoli, E. Petrelli, A. Cioppi, L. Ortona, A. De Luca, N. Petrosillo, P. Noto, P. Narciso, P. Salcuni, A. Antinori, P. De Longis, V. Vullo, M. Lichtner, G. Pastore, G. Minafra, A. Chirianni, L. Loiacono, M. Piazza, S. Nappa, N. Abrescia, M. De Marco, A. Colomba, T. Prestileo, C. De Stefano, A. La Gala, T. Ferraro, A. Scerbo, P. Grima, P. Tundo, E. Pizzigallo, M. D’Alessandro, B. Grisorio, and S. Ferrara. The Nice Cohort (France): Central coordination: C. Pradier, E. Fontas, and C. Caissotti: participating physicians: P. Dellamonica, L. Bentz, E. Bernard, S. Chaillou, F. De Salvador-Guillouet, J. Durant, R. Guttman, L. Heripret, V. Mondain-Miton, I. Perbost, B. Prouvost-Keller, P. Pugliese, V. Rahelinirina, P.M. Roger, and F. Vandenbos. SHCS (Switzerland): E. Bernasconi, H. Bucher, P. Bürgisser, S. Cattacin, M. Egger, P. Erb, W. Fierz, M. Fischer, M. Flepp, A. Fontana, P. Francioli (president), H.J. Furrer (chair of the clinical and laboratory committee), M. Gorgievski, H. Günthard, B. Hirschel, L. Kaiser, C. Kind, T. Klimkait, B. Ledergerber, U. Lauper, M. Opravil, F. Paccaud, G. Pantaleo, L. Perrin, J.C. Piffaretti, M. Rickenbach (head of the data center), C. Rudin (chair of the Mother and Child Substudy), J. Schüpbach, R. Speck, A. Telenti, A. Trkola, P. Vernazza (chair of the scientific board), R. Weber, and S. Yerly.

REFERENCES

1. Carr A, Cooper DA. Adverse effects of antiretroviral therapy. Lancet 2000;356:142330 .

2. Walli R, HerfortO, Michl GM, et al. Treatment with protease inhibitors associated with peripheral insulin resistance and impaired oral glucose tolerance in HIV-1-infected patients. AIDS 1998;12:F167-F173.

3. Vergis EN, Paterson DL, Wagener MM, Swindells S, Singh N. Dyslipidaemia in HIV infected patients: association with adherence to potent antiretroviral therapy. Int J STD AIDS 2001;12:463-8.

4. Galli M, Ridolfo AL, Adorni F, et al. Body habitus changes and metabolic alterations in protease inhibitor-naive HIV-1-infected patients treated with two nucleoside reverse transcriptase inhibitors. J Acquir Immune Defic Syndr 2002;29:21-31.

5. Friis-Mфller N, Weber R, Reiss P, et al. Cardiovascular risk factors in HIV patient - association with antiretroviral therapy: results from the DAD study. AIDS 2003;17: 1179-93.

6. Carr A, Samaras K, Thorisdottir A, Kaufmann GR, Chisholm DJ, Cooper DA. Diag nosis, prediction, and natural course of HIV-1 protease-inhibitor-associated lipodystrophy, hyperlipidaemia, and diabetes mellitus: a cohort study. Lancet 1999;353:2093-9.

7. Henry K, Melroe H, Huebsch J, et al. Severe premature coronary artery disease with protease inhibitors. Lancet 1998;351:1328. 8. Karmochkine M, Raguin G. Severe coronary artery disease in a young HIV-infected man with no cardiovascular risk factor who was treated with indinavir. AIDS 1998;12 2499.

9. Flynn TE, Bricker LA. Myocardial infarction in HIV-infected men receiving protease inhibitors. Ann Intern Med 1999;131:548.

10. Vittecoq D, Escaut L, Monsuez JJ. Vascular complications associated with use of HIV protease inhibitors. Lancet 1998;351:1959. 11. Escaut L, Monsuez JJ, Chironi G, et al. Coronary artery disease in HIV infected patients. Intensive Care Med 2003;29:969-73. 12. Moore RD, Keruly JC, Lucas G. Increas ing incidence of cardiovascular disease in HIV-infected persons in care. Presented at the 10th Conference on Retroviruses and
Opportunistic Infections, Boston, February 10-14, 2003:132. abstract

13. Currier J, Taylor A, Boyd F, et al. Coronary heart disease in HIV-infected individuals: associations with antiretroviral therapy. Antiviral Ther 2002;7:L37. abstract.

14. Coplan PM, Nikas A, Japour A, et al. Incidence of myocardial infarction in randomized clinical trials of protease inhibitor-based antiretroviral therapy: an analysis of four different protease inhibitors. AIDS Res Hum Retroviruses 2003;19:449-55.

15. Bozzette SA, Ake CF, Tam HK, Chang SW, Louis TA. Cardiovascular and cerebrovascular events in patients treated for human immunodeficiency virus infection. $\mathrm{N}$ Eng J Med 2003;348:702-10.

16. Klein D, Hurley LB, Quesenberry CP Jr Sidney S. Do protease inhibitors increase the risk for coronary heart disease in patient with HIV-1 infection? J Acquir Immune Defi Syndr 2002;30:471-7.

17. Holmberg SD, Moorman AC, Williamson JM, et al. Protease inhibitors and cardiovascular outcomes in patients with HIV-1. Lancet 2002;360:1747-8.

18. Mary-Krause M, Cotte L, Partisani M, Simon A, Costagliola D. Impact of treatment with protease inhibitor (PI) on myocardia infarction (MI) occurrence in HIV-infected men. In: Program and abstracts of the Eighth Conference on Retroviruses and Opportunistic Infections, Chicago, February 4-8, 2001 : 657. abstract

19. Klein D, Hurley L. Hospitalizations for coronary heart disease and myocardial in farction among men with HIV-1 infection: additional follow-up. Presented at the 10th Conference on Retroviruses and Opportunistic Infections, Boston, February 10-14, 2003 . 747. abstract.

20. Expert Panel on Detection, Evaluation, and Treatment of High Blood Cholesterol in Adults. Executive summary of the Third Report of the National Cholesterol Education Program (NCEP) Expert Panel on Detection, Evaluation, and Treatment of High Blood Cholesterol in Adults (Adult Treatment Panel III). JAMA 2001;285:2486-97.

21. Carr A, Emery S, Law M, Puls R, Lundgren JD, Powderly WG. An objective case defini- tion of lipodystrophy in HIV-infected adults: a case-control study. Lancet 2003;361:726-

22. 1993 Revised classification system for HIV infection and expanded surveillance case definition for AIDS among adolescents and adults. MMWR Recomm Rep 1992;41(RR17):1-19.

23. Tunstall-Pedoe H, Kuulasmaa K, Amouyel P, Arveiler D, Rajakangas AM, Pajak A. Myocardial infarction and coronary deaths in the World Health Organization MONICA Project: registration procedures, event rates, and case-fatality rates in 38 populations from 21 countries in four continents. Circulation 1994;90:583-612.

24. The D:A:D Study: Data Collection on Adverse Events of Anti-HIV Drugs: study documents. (Accessed September 19, 2003, at http://www.cphiv.dk/dad/.)

25. WHO MONICA Project. MONICA manual, part IV: event registration. (Accessed September 19, 2003, at http:/www.ktl.fi/ publications/monica/manual/part4/iv-1. htm.)

26. Mocroft A, Vella S, Benfield TL, et al. Changing patterns of mortality across Europe in patients infected with HIV-1. Lancet 1998;352:1725-30.

27. Law M, Friis-Mфller N, Weber R, et al. Modelling the 3-year risk of myocardial infarction among participants in the Data Collection on Adverse Events of Anti-HIV Drugs (DAD) study. HIV Med 2003;4:1-10.

28. Berenson GS, Srinivasan SR, Bao W, Newman WP III, Tracy RE, Wattigney WA Association between multiple cardiovascular risk factors and atherosclerosis in children and young adults: the Bogalusa Heart Study. N Engl J Med 1998;338:1650-6. 29. Kuulasmaa K, Tunstall-Pedoe H, Dobson A, et al. Estimation of contribution of changes in classic risk factors to trends in coronary-event rates across the WHO MONICA Project populations. Lancet 2000;355:67587.

30. Tunstall-Pedoe H. Myth and paradox of coronary risk and the menopause. Lancet 1998;351:1425-7.

Copyright (c) 2003 Massachusetts Medical Society. 